\title{
The Effect of Education on Hemodialysis Patients' Fatigue and Self-Care
}

\author{
Eğitimin Hemodiyaliz Hastalarında Yorgunluk \\ ve Öz Bakrm Üzerine Etkisi
}

\author{
Gonca DEVECi ${ }^{1}$ (D) , Hatice TEL AYDIN ${ }^{2}$ (D)
}

\begin{abstract}
Aim: The study was done to evaluate the effect of education on the fatigue and self-care of patients receiving hemodialysis treatment.

Method: The study sample consisted of 70 patients, randomly selected (35 controls and 35 intervention groups). The study datas were obtained by using the Patient Identification Form, Piper Fatigue Scale and Self-Care Agency Scale. Individual training on the content supporting coping with fatigue and selfcare power was given to patients in the intervention group. Piper Fatigue Scale and Self-Care Agency Scale were reapplied to all patients at the 3th and 6th months following the completion of the training sessions.
\end{abstract}

Results: In the pre-training evaluation, $\% 88.6$ of the intervention group and $91.4 \%$ of the control group experienced fatigue. The mean self-care score of the the intervention group was 86.20 and the control group was 79.11. In addition, there was no significant difference between the intervention and control groups in terms of their fatigue and self-care scores. In the evaluations at the third and sixth months, the control group's total fatigue and self-care scores had not changed (high fatigue scores and low self-care scores). Post intervention, the fatigue scores of the intervention group decreased while self-care scores increased, with a moderately significant negative correlation found between the fatigue and self-care score.

Conclusion: Results supported that individual training given to hemodialysis patients decreased fatigue scores and increased self-care scores.

Key Words: Hemodialysis; Fatigue; Self-Care; Education; Nursing.

\section{Özet}

Amaç: $\mathrm{Bu}$ araştırma, eğitimin hemodiyaliz tedavisi alan hastaların yorgunluk ve öz bakımlarına etkisini değerlendirmek amacıyla yapılmıştır.

Yöntem: Araştırma örneklemi rastgele seçilen (35 kontrol ve 35 müdahale grubu) 70 hastadan oluşmaktadır. Araştırma verileri Hasta Tanıtım Formu, Piper Yorgunluk Ölçeği, Öz-Bakım Gücü Ölçeği uygulanarak elde edildi. Müdahale grubundaki hastalara, yorgunlukla başetme ve öz bakım gücünü destekleyen içerikte bireysel eğitim verildi. Eğitimlerin tamamlanmasının ardından 3. ve 6. aylarda tüm hastalara Piper Yorgunluk Ölçeği ve Öz Bakım Gücü Ölçeği tekrar uygulandı.

Bulgular: Eğitim öncesi değerlendirmede müdahale grubundaki hastaların \%88,6'sının, kontrol grubundaki hastaların \%91,4'ünün yorgunluk yaşadığı, müdahale grubundaki hastaların öz-bakım puanı ortalamalarının 86,20, kontrol grubundaki hastaların öz bakım puanı ortalamalarının 79,11 olduğu, yorgunluk yaşama ve öz-bakım puanları açısından gruplar arasında farklılık olmadığı belirlendi. Üçüncü ve altıncı aylarda yapılan değerlendirmelerde kontrol grubunun toplam yorgunluk ve öz bakım puanları değişmedi (yüksek yorgunluk puanları ve düşük öz bakım puanları). Müdahale sonrası, müdahale grubunun yorgunluk puanları azalırken, öz bakım puanları artarken, yorgunluk ve öz bakım puanı arasında orta derecede anlamlı bir negatif korelasyon bulundu.

Sonuç: Çalışmanın sonuçları, hemodiyaliz hastalarına verilen bireysel eğitimin yorgunluk puanlarını azalttığını ve öz bakım puanlarını artırdığını desteklemektedir.

Anahtar Kelimeler: Hemodiyaliz; Yorgunluk; Öz Bakım; Eğitim; Hemşirelik.

\section{Geliș Tarihi / Submitted: 28 Haziran/June 2021 Kabul Tarihi / Accepted: 10 Ocak/Jan 2022}

${ }^{1}$ Uzm. Hemşire- Cumhuriyet Üniversitesi Sağlık Hizmetleri Araştırma ve Uygulama Hastanesi, Sivas, Türkiye

${ }^{2}$ Prof.Dr.- Cumhuriyet Üniversitesi Sağlık Bilimleri Fakültesi Hemşirelik Bölümü İç Hastalıkları Hemşireliği AD, Sivas, Türkiye

İletişim yazarı / Correspondence author: Gonca DEVECİ / E-posta: gdeveci@ msn.com, Adres: Cumhuriyet Üniversitesi Sağlık Hizmetleri Araştırma ve Uygulama Hastanesi, İç Hastalıkları Kliniği, Kampüs-Sivas, Türkiye.

18-22 Ekim 2017 tarihleri arasında Antalya'da düzenlenen 27. Ulusal Nefroloji Hemşireliği Kongresi'nde sözel bildiri olarak sunulmuştur. 


\section{INTRODUCTION}

Chronic kidney failure (CKD) is a chronic and progressive disease in which uremia result from a decrease in the patient's glomerular filtration rate (GFR). CKD in the world varies $14,9 \%$ (1). In Turkey, the prevalence of CKD was 15.7 \% (2).

Renal replacement therapies are needed when the glomerular filtration rate in GFR decreases below 15 $\mathrm{ml} / \mathrm{min} . / 1.73 \mathrm{~m}^{2}(3,4)$. The most widely used $(70.7 \%)$ renal replacement treatment in the world is hemodialysis (HD) (1). In Turkey, HD treatment is used with $76.93 \%$ of patients (5).

Although HD is a life-saving treatment option, it requires many important changes in patients' life processes. HD treatment can cause patients to experience many physical, mental and social problems $(2,6)$ with fatigue being one of the most common problems.

Fatigue is a subjective finding that includes emotional, cognitive and behavioral components, ranging from mild burnout affecting the whole body to unbearable exhaustion, preventing the person from performing his/her functions and using his normal capacity (7-10). Rates of fatigue, in patients with $\mathrm{HD}$, can vary between $12 \%$ and $97 \%$ (7-9). Patients receiving HD treatments may experience fatigue associated with anemia (11), nutrition (8), sleep disorders (12), physical inactivity (13) and psycho-social factors (14). Fatigue can also be a factor that negatively affects individual's diet, sexual activity, family and friendship relationships, work life and leisure activities (7). Not properly managed, fatigue also may negatively affects the self-care of individuals $(9,15)$. Self-care behaviors of patients with HD include many areas such as following the treatment regimen, regular medication use, compliance with HD treatment, fluid restriction, adherence to diet, communication, information and life satisfaction (16-18).

Nurses fulfill important responsibilities in assisting patients to manage their chronic diseases and nurses'effectiveness in disease management is increasing (19). By developing educational strategies, nurses can improve HD patients' adaptation to lifestyle changes, their coping with important complaints and their self-care skills (18). There are studies examining the level of fatigue in HD patients, and the relationships between fatigue (8) and exercise (9), sleep (12), anemia (20), psychosocial problems (12) and self-care and the factors affecting it (15).

However, there are no studies examining the effect of patient education on their fatigue and self-care. It is proposed that, with an effective nurse-patient education, the level of patient fatigue can be reduced, symptom control can be achieved and selfcare adequacy can be increased. In this study, the effects of individual nurse-patient education, with patients who have HD, on fatigue and self-care of patients was investigated.

\section{METHODS}

Using a randomized assignment of participants to control and intervention groups, this study evaluated the effect of patient education on the fatigue and self-care of participants with. Seventy participants, aged 18 and over, were selected. Inclusion criteria included: receipt of HD treatment for at least six months, HD treatment three times a week, no diagnosed psychiatric disease, hemoglobin value greater than $10 \mathrm{mg} / \mathrm{dl}$, conscious, and willing to participate in the study. Patients meeting the sample selection criteria were then randomized to the intervention and control groups.

Initially, the Patient Identification Form, Piper Fatigue Scale, and Self-Care Agency Scale were given to the participants in both groups. The intervention group was then provided patient individual education in the form of three separate 30-minute sessions. The patient education materials developed by the researchers and included visual education materials, narration, question and answer, and discussion. In the first educaitonal session, the following content was covered: the concept of fatigue, causes of fatigue in patients with HD, 
dialysis treatment, diet and anemia. Content covered in the second education session included problems related to fatigue (such as sleep problems, stress, physical activity problems). The final education session addressed approaches to improve the participant's coping with their fatigue and approaches to further suppport self-care agency. The participants, completing all educational sessions were given a written educational booklet.

Data collection instruments were then administered to both groups three and six months after the individual educational sessions were completed. The following instruments were used to gather data as part of this research: 1) Patient Information form, 2) Piper Fatigue Scale (Piper et al, 1998), and 3) the Self-Care Agency Scale (Kearney \& Fleischer, 1979).

1) Patient Identification Form: This instrument, based on related literature, consisted of questions about HD treatment and participants' sociodemographic information such as age, gender, education level, and comorbid diseases, self-care activities and medications.

2) Piper Fatigue Scale: The scale developed by Piper and colleagues (1998) consists of a total of 22 items. Responses for each item was scored between 0-10. The patient's subjective perceptions about fatigue in the scale were evaluated in four sub-dimensions (behavior/ violence sub-dimension, sensory sub-dimension and cognitive/mental sub-dimension). Subdimension scores were obtained by dividing the number of items by the total sumof all items in that sub-dimension. The total fatigue score was derived by summing the scores of the 22 items and dividing them by the number of items. High scores obtained from the scale indicated that perceived fatigue level was high (21). The validity and reliability study of the scale for the Turkish society was conducted (22) and the Cronbach's alpha was 0.94 . In the current study, the Cronbach's alpha was 0.98 .

3) Self-Care Agency Scale: This insturment was developed Kearney and Fleischer (1979) to determine the ability and power of people to take care of themselves (23). The scale is based on four characteristics, namely active or passive response to situations, motivation, knowledge of health practices and self- esteem, and includes a total of 35 statements.

The Likert scale has 5 scores: "it never defines me at all" (0 points), "it does not define me very much" (1 point), "I have no idea" (2 points), "defines me a bit" (3 points), or "defines me very much" (4 points). Nine items were scored negatively. Evaluation was based on a total of 136 points. A total score below 82 was "low", 82-120 points was "medium" and above 120 points was "high" self-care power. A high total score indicated that the individual was independent and able to perform self-care (23). In Turkey, thevalidity and reliability of the self-care agency scale (24) identified a Cronbach's alpha of 0.90 .

\section{DATA ANALYSIS}

The datas analysis used SPSS 22. Percentages, $t$ tests and ANOVAs were used with the level of error set at 0.05 .

\section{ETHICAL CONSIDERATIONS}

The study was submitted to the University Ethics Committee who determined the research plan was ethically appropriate. Written permission was also obtained from the institution where the research would be conducted. All participants were informed about the study and their verbal and written consents were obtained. After the data collection process was completed, the patient education, provided to the intervention group, was also provided to the control group to assure the implementation of the equality principle.

\section{RESULTS}

As detailed in Table 1, the patients in the intervention and control groups had similar characteristics in terms of basic socio-demographic and disease characteristics ( $p>0.05$ ). 
Table 1. Socio-Demographic and Disease Characteristics of Intervention and Control Group Patients

\begin{tabular}{|c|c|c|c|c|c|c|}
\hline \multirow[t]{2}{*}{ Spesifications } & \multicolumn{2}{|c|}{ Intervention Group $(n=35)$} & \multicolumn{2}{|c|}{ Control Group (n=35) } & \multirow[t]{2}{*}{$\mathrm{X}^{2}$} & \multirow[t]{2}{*}{$\mathbf{p}$} \\
\hline & Number & $\%$ & Number & $\%$ & & \\
\hline \multicolumn{7}{|l|}{ Gender } \\
\hline Female & 18 & 51.4 & 19 & 54.2 & \multirow{2}{*}{0.57} & \multirow{2}{*}{0.811} \\
\hline Male & 17 & 48.6 & 16 & 45.8 & & \\
\hline \multicolumn{7}{|l|}{ Age } \\
\hline $31-40$ & 7 & 20.0 & 3 & 8.6 & \multirow{4}{*}{3.51} & \multirow{4}{*}{0.319} \\
\hline $41-50$ & 3 & 8.6 & 3 & 8.6 & & \\
\hline $51-60$ & 12 & 30.0 & 9 & 25.7 & & \\
\hline $61-70$ & 13 & 37.1 & 20 & 57.1 & & \\
\hline \multicolumn{7}{|l|}{ Education } \\
\hline Literate & 5 & 14.3 & 12 & 34.3 & \multirow{4}{*}{7.48} & \multirow{4}{*}{0.058} \\
\hline Primary education & 20 & 57.1 & 20 & 57.1 & & \\
\hline Highschool & 7 & 20.0 & 3 & 8.6 & & \\
\hline University & 3 & 8.6 & 0 & 0.0 & & \\
\hline \multicolumn{7}{|l|}{ Marital Status } \\
\hline Married & 29 & 82.9 & 22 & 62.9 & \multirow{2}{*}{3.45} & \multirow{2}{*}{0.06} \\
\hline Single & 6 & 17.1 & 13 & 37.1 & & \\
\hline \multicolumn{7}{|l|}{ Working Status } \\
\hline Working & 6 & 17.1 & 4 & 11.4 & \multirow{2}{*}{0.46} & \multirow{2}{*}{0.498} \\
\hline Not working & 29 & 82.9 & 31 & 88.6 & & \\
\hline \multicolumn{7}{|l|}{ Occupational Status } \\
\hline Housewife & 16 & 45.7 & 19 & 54.3 & & \\
\hline Officer & 4 & 11.4 & 1 & 2.9 & & \\
\hline Retired & 12 & 34.3 & 13 & 37.1 & 2.43 & 0.657 \\
\hline Self-employment & 2 & 5.7 & 1 & 2.9 & & \\
\hline Worker & 1 & 2.9 & 1 & 2.9 & & \\
\hline Income Rate & & & & & & \\
\hline Good & 7 & 20.0 & 2 & 5.7 & & \\
\hline Mid & 15 & 42.9 & 20 & 57.1 & 3.49 & 0.174 \\
\hline $\mathrm{Bad}$ & 13 & 37.1 & 13 & 37.1 & & \\
\hline Family type & & & & & & \\
\hline Extended family & 29 & 82.9 & 23 & 65.7 & 260 & 0101 \\
\hline Seed & 6 & 17.1 & 12 & 34.3 & 2.09 & 0.101 \\
\hline Disease Education & & & & & & \\
\hline Yes & 20 & 57.1 & 19 & 54.3 & 058 & 0810 \\
\hline No & 15 & 42.9 & 16 & 47.7 & 0.50 & 0.010 \\
\hline Diet compliance & & & & & & \\
\hline Yes & 20 & 57.1 & 16 & 45.7 & 0.91 & 0330 \\
\hline No & 15 & 42.9 & 19 & 54.3 & 0.91 & 0.339 \\
\hline Using drug & & & & & & \\
\hline User & 34 & 97.1 & 32 & 91.4 & 106 & 0303 \\
\hline Non-user & 1 & 2.9 & 3 & 8.6 & 1.00 & 0.503 \\
\hline Using erythropoietin & & & & & & \\
\hline User & 33 & 94.3 & 32 & 91.4 & 021 & 0643 \\
\hline Non-user & 2 & 5.7 & 3 & 8.6 & & \\
\hline Comorbidity & & & & & & \\
\hline Yes & 24 & 68.6 & 26 & 74.3 & (2) & 0507 \\
\hline No & 11 & 31.4 & 9 & 25.7 & 0.28 & 0.591 \\
\hline
\end{tabular}

$* \mathrm{p}<0.05$ 
As detailed in Table 2, there was no significant difference between the patients in the intervention and control groups in terms of their descriptive characteristics such as fatigue, duration of fatigue, state of fatigue affecting their daily lives and coping behaviors ( $p>0.05)$.

As detailed in Table 3, no statistical difference was identified between the pre-education fatigue scores of the patients in either the intervention or the control groups $(p>0.05)$. However, the posteducation fatigue scores of the intervention group were significantly lower than those of the control group at both three and six months. There was also a statistically significant difference between the preand post-education total fatigue score averages of the intervention group at the third and sixth months with the scores decreasing significantly after the education. In the control group, there was no statistically significant difference between the preand post-education total fatigue score averages with the fatigue scores continuing to be high.

Table 2. Fatigue Characteristics of Patients Before Education

\begin{tabular}{|c|c|c|c|c|c|c|}
\hline \multirow[t]{2}{*}{ Characteristics } & \multicolumn{2}{|c|}{$\begin{array}{c}\text { Intervention Group } \\
(n=35)\end{array}$} & \multicolumn{2}{|c|}{$\begin{array}{c}\text { Control Group } \\
(n=35)\end{array}$} & \multirow[t]{2}{*}{$\mathbf{X}^{2}$} & \multirow[t]{2}{*}{$\mathbf{p}$} \\
\hline & & $\%$ & & $\%$ & & \\
\hline & & & & & & \\
\hline \multicolumn{7}{|l|}{ Fatigue } \\
\hline Available & 31 & 88.6 & 32 & 91.4 & \multirow{2}{*}{0.159} & \multirow{2}{*}{0.690} \\
\hline Absent & 4 & 11.4 & 3 & 8.6 & & \\
\hline \multicolumn{7}{|c|}{ The state of fatigue affecting daily life } \\
\hline Affecting & 27 & 87.0 & 29 & 90.6 & \multirow{2}{*}{1.30} & \multirow{2}{*}{0.105} \\
\hline Non-affecting & 4 & 13.0 & 3 & 9.4 & & \\
\hline \multicolumn{7}{|c|}{ Taking support to cope fatigue } \\
\hline Taking & 1 & 3.2 & 2 & 6.3 & \multirow{2}{*}{2.25} & \multirow{2}{*}{0.08} \\
\hline Non-taking & 30 & 96.7 & 30 & 93.7 & & \\
\hline \multicolumn{7}{|c|}{ Time to experience fatigue } \\
\hline For weeks & 9 & 31.4 & 6 & 18.7 & \multirow{2}{*}{1.29} & \multirow{2}{*}{0.204} \\
\hline For months & 22 & 68.6 & 26 & 81.3 & & \\
\hline \multicolumn{7}{|l|}{ Cause of fatigue } \\
\hline Hemodialysis & 26 & 80.0 & 18 & 56.2 & \multirow{2}{*}{5.85} & \multirow{2}{*}{$0.022 *$} \\
\hline Chronic renal failure & 5 & 20.0 & 14 & 43.8 & & \\
\hline \multicolumn{7}{|c|}{ Initiatives to reduce fatigue } \\
\hline Sleeping & 14 & 45.1 & 13 & 40.6 & \multirow{2}{*}{0.17} & \multirow{2}{*}{0.700} \\
\hline Resting & 10 & 32.2 & 13 & 40.6 & & \\
\hline Do nothing & 7 & 25.7 & 6 & 22.8 & & \\
\hline \multicolumn{7}{|c|}{ Complaints other than fatigue } \\
\hline Hypotension & 13 & 42.9 & 13 & 40.6 & \multirow{3}{*}{1.13} & \multirow{3}{*}{0.200} \\
\hline Muscle cramps & 11 & 37.1 & 15 & 46.8 & & \\
\hline Not & 7 & 20.0 & 4 & 12.5 & & \\
\hline
\end{tabular}

$* \mathrm{p}<0.05$

Table 3. Fatigue Scores of Individuals in Intervention and Control Groups in Pre-and Post-Training Follow-up

\begin{tabular}{|l|c|c|c|c|c|}
\hline Total fatigue scores & $\begin{array}{c}\text { Before } \\
\text { training }\end{array}$ & $\begin{array}{c}\text { Third month } \\
\text { after training }\end{array}$ & $\begin{array}{c}\text { Sixth month } \\
\text { after training }\end{array}$ & $\mathbf{F}$ & $\mathbf{\text { X }}$ \\
\hline & $\mathbf{X} \pm$ SD & $\mathbf{X} \pm$ SD & $4.67 \pm 0.92$ & 266.40 & $0.001 *$ \\
\hline Intervention group & $7.24 \pm 1.62$ & $4.84 \pm 1.04$ & $7.75 \pm 1.42$ & 0.40 & 0.669 \\
\hline Control group & $7.71 \pm 1.35$ & $7.80 \pm 1.55$ & 10.73 & & \\
\hline $\mathbf{t}$ & 1.30 & 9.35 & $0.001 *$ & & \\
\hline $\mathbf{p}$ & 0.198 & $0.001 *$ & & \\
\hline
\end{tabular}

$* \mathrm{p}<0.05$ 
As detailed in Table 4, There was no statistical difference between the pre-education self-care scores of the patients in the intervention and control groups ( $\mathrm{p}>0.05)$.

There was no statistically significant difference between the pre- and post-education control group self-care score averages and the self-care, with posteducation self-care scores remaining low.

Self-care scores of the intervention group were significantly higher than those of the control group at post-education measurements. Furthermore, there was a statistically significant difference between the pre- and posteducation self-care score averages of the patients in the intervention group with the selfcare scores of the patients increasing significantly.

An adddition finding was that of a significant, negative and medium-level relationship between the fatigue and self-care scores of the patients in both the intervention and control groups. It was also found that self-care decreased with increasing fatigue level in both groups.

\section{DISCUSSION}

Chronic diseases negatively affect the self-care activities of individuals. It is important for patients, experiencing $\mathrm{HD}$, to develop self-care strategies related to fatigue $(9,25-28)$.

Akin et al. (2013) found that only $9.5 \%$ of patients with HD were independent in terms of their self-care (29). In contrast, some studies found self-cares to be moderate in patients with HD $(24,30,31)$. Research findings have supported that patient education results in an increase in the self-care score of patients with $\mathrm{HD}(16,32,33)$.

In this study, self-care scores of the intervention and control groups were similar to the results in the literature. While self-care scores continued at a low level in the control group after education, a significant increase was observed in the scores of the intervention group. This result supports that individual patient education can increase patient self-care scores.

Fatigue is a common problem in patients experiencing HD. In the pre-training stage, of the research, it was determined that the rate of fatigue was very high in both the control and intervention groups. In previous studies, patients with HD had a very high rate of fatigue ranging from $65.4 \%$ (25) to $92.9 \%(25-28)$ and approximately one third of patients had high levels of fatigue (25). Some studies have shown that, as patients' with HD general fatigue level increases, daily activities are also increasingly effected by fatigue $(9,34,35)$. In This study identified high rates of patients indicating that fatigue affected their daily lives (intervention $77.1 \%$; control 88.6\%). This is an important finding as supports that learning coping strategies with fatigue is important for patients.

Although fatigue is an important problem in patients with HD, the literature states that patients do not generally apply effective approaches to cope with fatigue other than resting (36,37). In this study, most of the patients stated that they preferred to sleep and rest in order to cope with fatigue.

Table 4. Pre-training and After Self-Care Scores of Patients in Intervention and Control Groups

\begin{tabular}{|c|c|c|c|c|}
\hline & \multicolumn{2}{|c|}{ Self-Care Agency Scale } & & \\
\hline & Intervention group & Control group & & \\
\hline & $\mathbf{X} \pm$ SD & $\mathbf{X} \pm \mathrm{SD}$ & $\mathbf{t}$ & $\mathbf{p}$ \\
\hline Pre-training & $86.20 \pm 16.00$ & $79.11 \pm 14.65$ & 1.93 & 0.058 \\
\hline 3rd months after training & $115.40 \pm 11.13$ & $78.68 \pm 14.47$ & 11.89 & $0.001 *$ \\
\hline 6th months after training & $118.97 \pm 11.18$ & $76.91 \pm 15.14$ & 13.21 & $0.001 *$ \\
\hline $\mathbf{F}$ & 133.92 & 1.40 & & \\
\hline $\mathbf{p}$ & $0.001 *$ & 0.252 & & \\
\hline
\end{tabular}

$* \mathrm{p}<0.05$ 
Both Mohamed (2014) and Patterson et al. (2013) reported that patient education reduced fatigue (37, 38). Mohamed's study (2014) identified that patient fatigue score averages in both the intervention and control groups were similar before education related to coping with fatigue, with the intervntion group's average fatigue score decreasing after the education, while the control group's average fatigue score remained high. In this study the fatigue score averages of both intervention and control groups patients before the education were found to be high. While the total fatigue scores of the intervention group decreased three and six months after the education, the fatigue scores of the control group did not change. This result supports that education is effective in decreasing fatigue levels in the patients experiencing HD.

Evaluation of fatigue and self-care in patients with HD is important to develop approaches that will contribute to reduce fatigue in these patients (9). According to Levey et al. (2007), psychosocial problems and fatigue lead to changes in individuals' daily life activities and decreased self-care (15). Ak1n et al. (2013) found a negative correlation between patient fatigue and self-care (29). Slesnick et al. (2015) found that self-care education reduced fatigue (39). In the current study, there was also a negative and significant correlation between fatigue and self-care score in the pre-education evaluation. Following the patient education, a negatively insignificant correlation between these variables assists in understanding the relationship between patient education and fatigue and self-care scores.

\section{CONCLUSION AND SUGGESTIONS}

In this study, results identified that patients with HD had high levels of fatigue and low self-care scores. Withthe control group, fatigue scores were high and self-care scores were low at the first evaluation, and these results did not change at the third and sixth month evaluations. Following patient education, the patients in the intervention group had decreased fatigue scores and increased self-care scores.

These results support that patient education is important to assist patients with HD to better cope with fatigue and increase their self-care. As a result, patient eductions programs for patients with HD should be designed to assist these patients to cope with fatigue and support their self-care. It is also recommended that the organized education programming be developed by hemodialysis and/or nephrology nurses in order that self-care and fatigue symptoms, specific to patients with HD, are evaluated and addressed.

\section{ETHICS COMMITTEE APPROVAL}

Ethics committee approval: Sivas Cumhuriyet University Non-Invasive Clinical Research Ethics

Committee (Date and no: 17.04.2015/ 2015-04-08)

\section{INFORMED CONSENT}

From the study participants informed consent was obtained.

\section{CONFLICT OF INTEREST}

Any financial or other interest in the study there is no conflict.

\section{FINANCIAL SUPPORT}

Any institution/organization related to the study has no financial support.

\section{PEER REVIEW}

External independent, double blind.

\section{AUTHOR CONTRIBUTIONS}

Idea and design: HTA, GD

Data collection: GD

Data analysis and interpretation: GD

Preparation of the article: HTA, GD

Critical review: HTA, GD 


\section{References}

1. United States Renal Data System. (USRDS). (2020). Annual Data Report: End Stage Renal Disease // 1: Incidence, Prevalence, Patient Characteristics, and Treatment Modalities, 2020. https://adr.usrds.org/2020/end-stage-renal-disease/1-incidenceprevalence-patient-characteristics-and-treatment-modalities. Date of access: 22 July 2021.

2. Süleymanlar G, Utaş C, Arınsoy T, Ateş K, Altun B, Ecder T, and et al. A Population Based Survey of Chronic Renal Disease in Turkey - The CREDIT study. Nephrol Dial Transplant. 2011; 26:1862-71. DOI: 10.1093/ndt/gfq656

3. Clinical Practice Guideline for the Evaluation and Management of Chronic Kidney Disease (KDIGO 2012). Kidney Int Suppl, 2013;3: 1-150.

4. Lewis SL, Heitkemper MM, Dirksen SR, O’brien PG, Bucher L. Medical-Surgical Nursing: Assessment and Management of Clinical Problems. 2-Volume Set. 7e Hardcover -April.2007: 6,1197-1130.

5. Süleymanlar G, Ateş K, Seyahi N. T.C. Sağlık Bakanlı̆̆ı ve Türk Nefroloji Derneği Ortak Raporu. $2020 ; 136$. http://www.nefroloji.org.tr/folders/file/registry_2019. Date of access: 20 July 2021.

6. John JF, Thomas VJ. The Psychosocial Experience of Patients With End-Stage Renal Disease and Its Impact on Quality of Life: Findings from a Needs Assessment to Shape a Service. ISRN Nephrology.2013;1-8. http://dx.doi.org/10.5402/2013 1308986

7. Bonner A, Caltabiano M, Berlund L. Quality of Life, Fatigue, and Activity in Australians With Chronic Kidney Disease: A Longitudinal Study. Nursing \& Health Sciences.2013; 15(3):360-367. DOI: 10.1111/nhs.12038

8. Horigan AE, Rocchiccioli J, Trimm D. Dialysis and Fatigue: Implications For Nurses - A Case Study Analysis. Medsurg Nurs.2012; 21(3): 158-175.

9. Horigan AE, Schneider SM, Docherty S, Barroso J. The Experience and Self-Management of Fatigue in Patients on Hemodialysis. Nephrol Nurs J.2013; 40 (2):113-22.

10. Herdman, T.H. ve Kamitsuru, S. (Eds.). (2014). NANDA International Nursing Diagnoses: Definitions \& Classification, 20152017.Oxford, Wiley Blackwell, 133-357.

11. Finkelstein F, Story K, Firanek C, Mendelssohn D, Barre P, and et al. Health-Related Quality of Life and Hemoglobin Levels in Chronic Kidney Disease Patients. Clin J Am Soc Nephrol.2009; 4: 33-38. DOI: 10.2215 /CJN. 00630208

12. Joshwa B, Khakha CD, Mahajan S. Fatigue and Depression and Sleep Problems Among Hemodialysis Patients in a Tertiary Care Center. Saudi J KidneyDis Transpl.2012; 23(4):729-735. DOI: 10.4103/1319-2442.98149

13. Gould DW, Brown G, Watson E,Viana J, Smith A. Physiological Benefits of Exercise in Pre-Dialysis Chronic Kidney Disease. Nephrology. 2014; 19:519-527. DOI:10.1111/nep.12285

14. Öztürk B. (2011) Hemodiyaliz Tedavisini Sürdüren Hastalarda Tedaviye Uyumun ve Eğitim Gereksinimlerinin Değerlendirilmesi. İstanbul Bilim Üniversitesi Sağlık Bilimleri Enstitüsü. İstanbul, 123.

15. Levey AS, Andreoli S, Du Bose T, Provenzano R, Collins AJ. Ckd: Common, Harmful, and Treatable World Kidney Day. Am J Kidney Dis. 2007; 49 (2):175-179. DOI: 10.1053/j.ajkd.2006.12.013

16. Rahimi F, Gharib, A, Beyramijam M, Naseri O. Effect of Self-Care Education on Self Efficacy in Patients Undergoing Hemodialysis. Life Science Journal. 2014; 11:136-140. ISSN: 2372-613X (Online); doi prefix: 10.7537

17. Rossi AP, Burris DD, Lucas FL, Crocker GA, Wasserman JC. Effects of A Renal Rehabilitation Exercise Program in Patients With CKD: A Randomized, Controlled Trial. Clinical journal of the American Society of Nephrology. 2014; 9 (12):2052-2058. DOI:10.2215/CJN.11791113

18. Simmons L. Dorthea Orem's Self Care Theory as Related To Nursing Practice in Hemodialysisi. Nephrology Nursing. 2009; 36(4):419-421.

19. International Council of Nurses (ICN). (2010) Delivering Quality, Serving Communities: Nurses Leadıng Chronıc Care International Day. http://www.icn.ch/publications/2010-delivering-quality-serving-communities-nurses-leading-chroniccare/Date of access: 20 July 2021.

20. Johansen KL, Finkelstein FO, Revicki DA, Evans C, Wan S, and et al. Systematic Review of The Impact of ErythropoiesisStimulating Agents on Fatigue in Dialysis Patients. Nephrol Dial Transplant. 2012; 27: 2418-25. DOI: 10.1093/ndt/gfr697

21. Piper BF, Dibble SL, Dodd MJ, Weiss MC, Slaughter RE, Paul SM. The Revised Piper Fatigue Scale: Psychometric Evaluation in Women With Breast Cancer. Oncology Nursing Forum. 1998; 25(4):677-684. 
22. Can G. (2001) Evaluation of Fatigue and Care Needs in Breast Cancer Patients. Istanbul University Institute of Health Sciences. İstanbul.130.

23. Kearney B, Fleisher B. Development of an Instrument to Measure Exercise of Self-Care Agency. Res Nurs Health. 1979; 2:2534. DOI: $10.1002 /$ nur.4770020105

24. Nahcivan N. (1993) Self-Care Power and the Effect of Family Environment on Healthy Youngs, Istanbul University Institute of Health Sciences. Istanbul, 106.

25. Biniaz V, Tayybi A, Nemati E. Different Aspects of Fatigue Experienced by Patients Receiving Maintenance Dialysis in Hemodialysis Units. Nephro-Urology. 2013;5(4):897-900. DOI: 10.5812/numonthly.11667

26. Davison SN, Jhangri GS. The İmpact of Chronic Pain On Depression, Sleep, and The Desire to Withdraw From Dialysis in Hemodialysis Patients. Journal of Pain and Symptom Management. 2005;30(5):465-473. DOI:10.1016 /j.jpainsymman.2005.05.013

27. Jablonski A. The Multidimensional Characteristics of Symptoms Reported by Patients on Hemodialysis. Nephrology Nursing Journal. 2007; 34 (1):29-37.

28. Caplin B, Kumar S, Davenport A. Patients Perspective of Haemodialysis-Associated Symptoms. Nephrol Dial Transplant. 2011; 26(8):2656-63. DOI: 10.1093 /ndt /gfq763

29. Akın S, Mendi B, Öztürk B, Cinper C, Durna Z. Assessment of Relationship Between Self-Care and Fatigue and Loneliness in Haemodialysis Patients. J Clin Nurs.2013; 23(5-6): 856-64. doi: 10.1111/jocn.12248. PMID: 23808612 DOI: 10.1111/jocn. 12248

30. Ovayolu N, Torun S, Uçan Ö, Elçi A. Hemodiyaliz Hastalarının Öz-Bakıma İlişkin Tutumları ve Sosyodemografik Özellikleri Özbakım Gücü Arasındaki İlişki. Nefroloji Hemşireliği Dergisi.2007; 21-25.

31. Bağ E, Mollaoğlu M. The Evaluation of Self-Care and Self-Efficacy in Patients Undergoing Hemodialysis. Journal of Evaluation in Clinical Practice.2010;16:605-610. DOI:10.1111/j.1365-2753.2009.01214.x

32. Fırat Kılıç H, Alpar ŞE. The Effect of Group Training İmplemented on Hemodialysis Patients for Their Stress Management, Psychosocial Adjustment and Self-Care Strength. International Journal of Human Sciences.2016; 13(1):654-767. Retrieved from https://www.j-humansciences.com/ojs/index.php/IJHS/article/view/3422.

33. Mohamed SK, El-Fouly Y, El-Deeb M. Impact Of A Desıgned Self-Care Program on Selected Outcomes Among Patients Undergoing Hemodialysis. Impact Journals. 2016;4, (5):73- 90.

34. Lee B, Lin CC, Chaboyer W, Chiang CL, Hung CC. The Fatigue Experience of Haemodialysis Patients in Taiwan. J Clin Nurs.2007; Feb,16(2),407-13. DOI: 10.1111/j.1365-2702.2005.01409.x

35. Heidarzadeh M, Atashpeikar S, Jalilazaret T. Relationship Between Quality of Life and Self-Care Ability in Patients Receiving Hemodialysis. IJNMR.2010;15(2): 71-76.

36. Horigan AN, Barroso JV. A Comparison of Temporal Patterns of Fatigue in Patients on Hemodialysis. Nephrol Nurs J.2016; 43(2): 129-139.

37. Mohamed SA. The Effectiveness of an Educational Intervention on Fatigue in Hemodialysis Patients: A Randomized Controlled Trial. IOSR Journal of Nursing and Health Science.2014; 3(4):40-50. DOI:10.9790/1959-03434050

38. Patterson E, Wan YWT, Sidani S. Nonpharmacological Nursing Interventions for the Management of Patient Fatigue: A Literature Review. Journal of Clinical Nursing.2013; 22:2668-2678. DOI: 10.1111/jocn.12211

39. Slesnick N, Pienkos S, Doss-Mcquitty S, Schiller B. The Chronic Disease Self-Management Program - A Pilot Study in Patients Undergoing Hemodialysis. Nephrol News Issues.2015; 29(4):22-3,27-8,30-2. 